\title{
Regarding the real diversity of Glyptodontidae (Mammalia, Xenarthra) in the late Pliocene (Chapadmalalan Age/Stage) of Argentina
}

\author{
ALFREDO E. ZURITA ${ }^{1}$, MATÍAS TAGLIORETTI ${ }^{2}$, MARTÍN DE LOS \\ REYES $^{3}$, FRANCISCO CUADRELLI ${ }^{1}$ and DANIEL POIRE ${ }^{4}$ \\ ${ }^{1}$ Centro de Ecología Aplicada del Litoral/CECOAL-CONICET y Universidad Nacional del \\ Nordeste, Ruta 5, km 2.5 CC 128 (3400), Corrientes, Argentina \\ ${ }^{2}$ Facultad de Ciencias Exactas y Naturales, Instituto de Geología de Costas y del Cuaternario/IIMYC-CONICET, \\ Universidad Nacional de Mar del Plata, Calle Funes, n 3350 (7600), Mar del Plata, Buenos Aires, Argentina \\ ${ }^{3}$ Facultad de Ciencias Naturales y Museo de La Plata, Paseo del Bosque, s/n (1900), La Plata, Buenos Aires, Argentina \\ ${ }^{4}$ Centro de Investigaciones Geológicas/CIG-CONICET-UNLP, Calle 1, nº 644 (1900), La Plata, Buenos Aires, Argentina
}

Manuscript received on February 23, 2015; accepted for publication on April 10, 2015

\begin{abstract}
A large diversity of Glyptodontidae has been proposed as characterizing the Chapadmalalan Age (Pliocene). Most of these taxa were recognized on the basis of partial dorsal carapaces and/or caudal tubes, whereas the main diagnostic characteristic is a particular morphology of the exposed surface of the osteoderms. From a biostratigraphic point of view some species are biostratigraphically important. The Upper Chapadmalalan is based on the Paraglyptodon chapadmalensis biozone. Both the re-evaluation of the type and referred materials and new significant findings from the Chapadmalal and El Polvorín Formations indicate that the diversity of Pliocene Glyptodontidae is more limited than previously supposed. The particular morphology of the exposed surface of the osteoderms that characterizes some of the species actually corresponds to a taphonomic alteration, which results in a non-real ornamentation pattern. Thus, the Glyptodontinae $P$. chapadmalensis must be replaced as a fossil guide because neither this species nor the species included in the genera Urotherium, Trachycalyptus and Lomaphorus are well characterized. Taking into account the diversity of Glyptodontidae for this lapse, the Glyptodontinae are very scarce (a situation that contrasts with its records in the Pleistocene), whereas Eosclerocalyptus, "Plohophorini" (Plohophorus) and Doedicurinae (cf. Eleutherocercus antiquus) are among the most recorded taxa.
\end{abstract}

Key words: Diversity, Glyptodonts, Osteoderms, Pliocene, Southern South America.

\section{INTRODUCTION}

Glyptodonts (Xenarthra, Glyptodontidae) constitute an extinct clade of cingulates widely distributed in North and South America (Carlini and Zurita 2010), with records that span from the late Eocene

Correspondence to: Alfredo Eduardo Zurita

E-mail: aezurita74@yahoo.com.ar of Patagonia to the early Holocene of the Pampean region of Argentina (Soibelzon et al. 2012). From a taxonomic point of view, most of the genera were recognized in the current territory of Argentina, although the knowledge of glyptodonts from other regions of South and North America has been largely improved over the last decades (Gillette 
and Ray 1981, Carlini et al. 2008a, b, Porpino et al. 2010, 2014, Zurita et al. 2011a, 2013).

From a morphological perspective, the Quaternary taxa are, in general, well known, and as a consequence of this, many of the recognized lineages of Glyptodontidae have been characterized by complete (or almost complete) specimens coming from the Pleistocene units, especially from the Pampean region of Argentina (Burmeister 187074, Ameghino 1889, Lydekker 1895). This situation changes dramatically in what concerns the knowledge of Paleogene and Neogene glyptodonts, which is much more restricted. In fact, several taxa are still recognized on the basis of fragments of the dorsal carapace and/or caudal armor (e.g. Glyptatelinae and "Hoplophorinae" Palaehoplophorini; Hoffstetter 1958, Scillato-Yané 1977).

The above-mentioned situation is evident regarding the Pliocene period ( $c a$. 5.3-2.6 Ma), in which many species have been recognized, but only a few are well characterized. This is also clear regarding the diversity of glyptodonts proposed as characterizing the Chapadmalalan Age/Stage (late Pliocene), which comprises at least 10 genera and species (cf. Eleutherocercus Koken, Panochthus Burmeister, Eosclerocalyptus C. Ameghino, Plohophorus Ameghino, Plohophoroides Castellanos, Paraglyptodon Castellanos, Trachycalyptus Ameghino in Rovereto, Lomaphorus Ameghino, Urotherium Castellanos, Nopachthus Ameghino and Palaeodaedicurus Castellanos) (Ameghino 1908, Castellanos 1939, 1940, 1941, Reig 1958, Scillato-Yané et al. 1995, Carlini and Scillato-Yané 1999, Zurita et al. 2011b, 2014, Zamorano et al. 2014). Since Ameghino's and Castellanos's times, most of these taxa have been recognized and characterized from materials exhumed from the marine cliffs cropping out between the localities of Mar del Plata and Miramar in Buenos Aires province, Argentina (Cione and Tonni 1996), coming from the Chapadmalal Formation (sensu Kraglievich 1952). In Ameghino's times, this area was known as "Cha- palmalán" (see Ameghino 1908). Since then, this diversity of glyptodonts has been classically documented as characterizing the Chapadmalalan interval (Kraglievich 1934, Reig 1958, Scillato-Yané et al. 1995, Carlini and Scillato-Yané 1999, Vizcaíno et al. 2004, Poiré et al. 2005). However, and as observed in other lapses (e.g. Pleistocene), the real diversity is clearly overestimated (see Zurita et al. 2011c).

As a result of new field works carried out in the Chapadmalal and Polvorín Formations (Pliocene) of the surroundings of the localities of Mar del Plata and Olavarría (Buenos Aires province) (Figure 1), several new and more complete remains of Glyptodontidae with strict geographic and stratigraphic control have been exhumed. In the present contribution, we carry out a careful taxonomic revision of some of the traditional species recognized

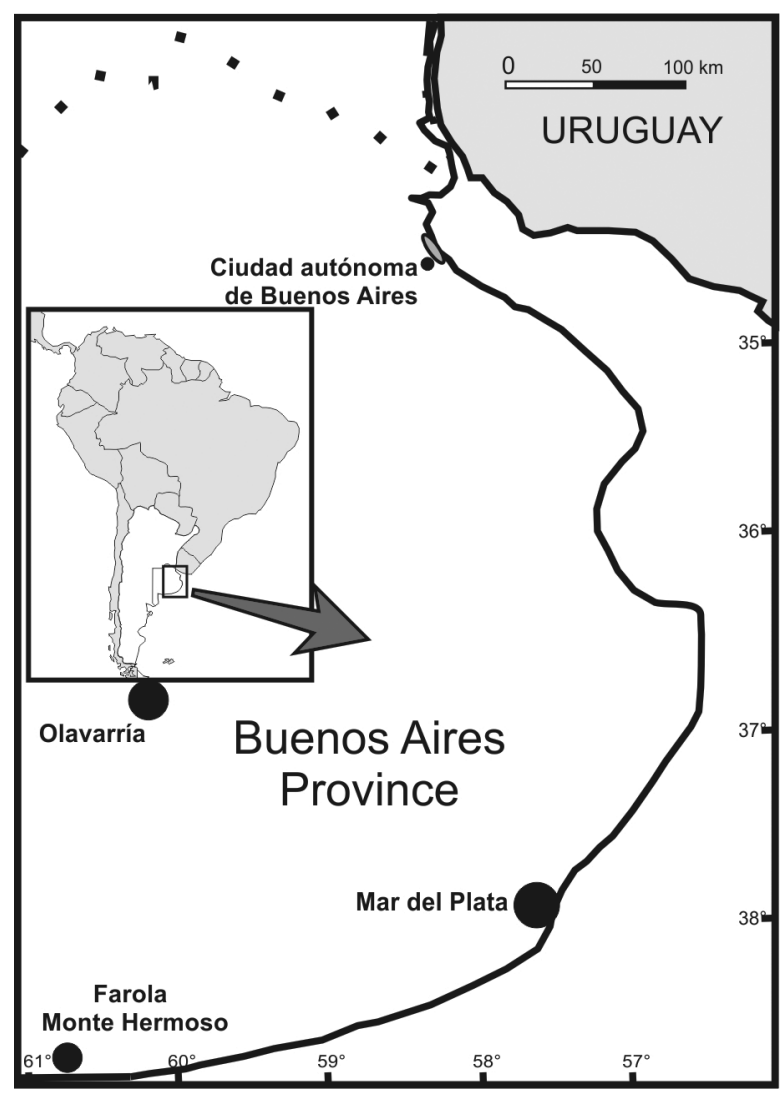

Figure 1 - Map showing Olavarría, Mar del Plata and Farola Monte Hermoso (Buenos Aires province, Argentina). 
for the Chapadmalalan lapse (Pliocene) and discuss the taxonomic status of other related glyptodonts. This may allow obtaining a more real approach of the diversity of this clade during part of the Pliocene.

\section{GEOLOGY AND CHRONOLOGY}

\section{Chapadmalal Formation (Fig. 2a)}

The Chapadmalal Formation (sensu Kraglievich 1952) outcrops almost continuously along $30 \mathrm{~km}$, from the towns of Playa Serena (38 $06^{\circ} 30.95^{\prime \prime} \mathrm{S}$ / 57³4'27.98”W) (Mar del Plata, General Pueyrredón) and Playa Prefectura (38 $15^{\circ} 35.27^{\prime}$ 'S / 5748'23.67’W) (Miramar, General Alvarado). The best outcroppings are located in the area belonging to Playa San Carlos (3807'24.74”S / 57³5'55.20”W; see Kraglievich 1952). This formation constitutes the stratotype of the Chapadmalalan Stage/Age. Zárate (1989) separated this unit into two Alloformations: Playa San Carlos and the overlaying Playa Los Lobos. Impactites from the paleosol number 6 from Playa los Lobos Alloformation were dated at $c a .3 .27 \pm 0.08$ (Schultz et al. 1998). From a magnetostratigraphic viewpoint, some authors (e.g. Orgeira 1987) suggest an age between 4.5 and 3.4 Ma. More recently, the age of the Chapadmalal Formation (=Playa San Carlos and Los Lobos Alloformations sensu Zárate 1989) was limited between 4.5/5.0 and 3.2 Ma (Zárate 2005). This unit is composed mainly of reddish brown clayey silt and sandy silts, poorly consolidated and with scarce calcium carbonate forms. Bt paleosols are well developed, showing abundant vertebrate paleoburrows.

\section{El Polvorín Formation (Fig. 2b)}

El Polvorín Formation is located in the intermountain Neogene strata $\left(36^{\circ} 59\right.$ ' 8.37 " S $60^{\circ} 13$ ' 40.52 " W), belonging to the "Sistema de Tandilia" (Nágera 1940), near the city of Olavarría, Buenos Aires province, Argentina. The bearing levels are included in the "Calera Facies" (Poiré et al. 2005, 2007). This geological unit overlaps in discordance to the Loma Negra Formation (Borrelo 1966) of the Sierras Bayas Group (Poiré 1993), and is covered by the "La Esperanza" Formation (Poiré 2009). Recently, the age of the El Polvorín Formation was tentatively referred to $c a$. 3.55 Ma. (Gómez Samus et al. 2014).

\section{MATERIALS AND METHODS}

The chronological and biostratigraphic schemes used in this contribution follow Cione and Tonni (2005), Cione et al. (2007), and Tomassini et al. (2013). Stratigraphic schemes follow Kraglievich (1952), Zárate (1989), and Zárate and Fasano (1989) for the Chapadmalal Formation, and De los Reyes et al. (2013) for El Polvorín Formation. The systematics partially follows Hoffstetter (1958), Paula Couto (1979), McKenna and Bell (1997), and Fernicola (2008). The description and terminology for osteoderms follow mainly Zurita (2007a) and Krmpotic et al. (2009). Appendix I shows the specimens used for comparative study.

Institutional abbreviations

Ctes-Pz: Colección Paleontológica "Dr. Rafael Herbst”, Facultad de Ciencias Exactas y Naturales y Agrimensura (Universidad Nacional del Nordeste), Corrientes, Argentina; FM: Museo Municipal "Carlos Darwin", Punta Alta, Buenos Aires, Argentina; GCF: Grupo Conservacionista de Fósiles, Museo Paleontológico "Fray Manuel de Torres", San Pedro, Buenos Aires, Argentina; MACN: Sección Paleontología Vertebrados, Museo Argentino de Ciencias Naturales "Bernardino Rivadavia", Buenos Aires, Argentina; MLP: División Paleontología Vertebrados, Facultad de Ciencias Naturales y Museo, Universidad Nacional de La Plata, Argentina; MCNL: Museo de Ciencias Naturales de Lobería, Buenos Aires, Argentina; MCA: Museo de Ciencias Naturales "Carlos 

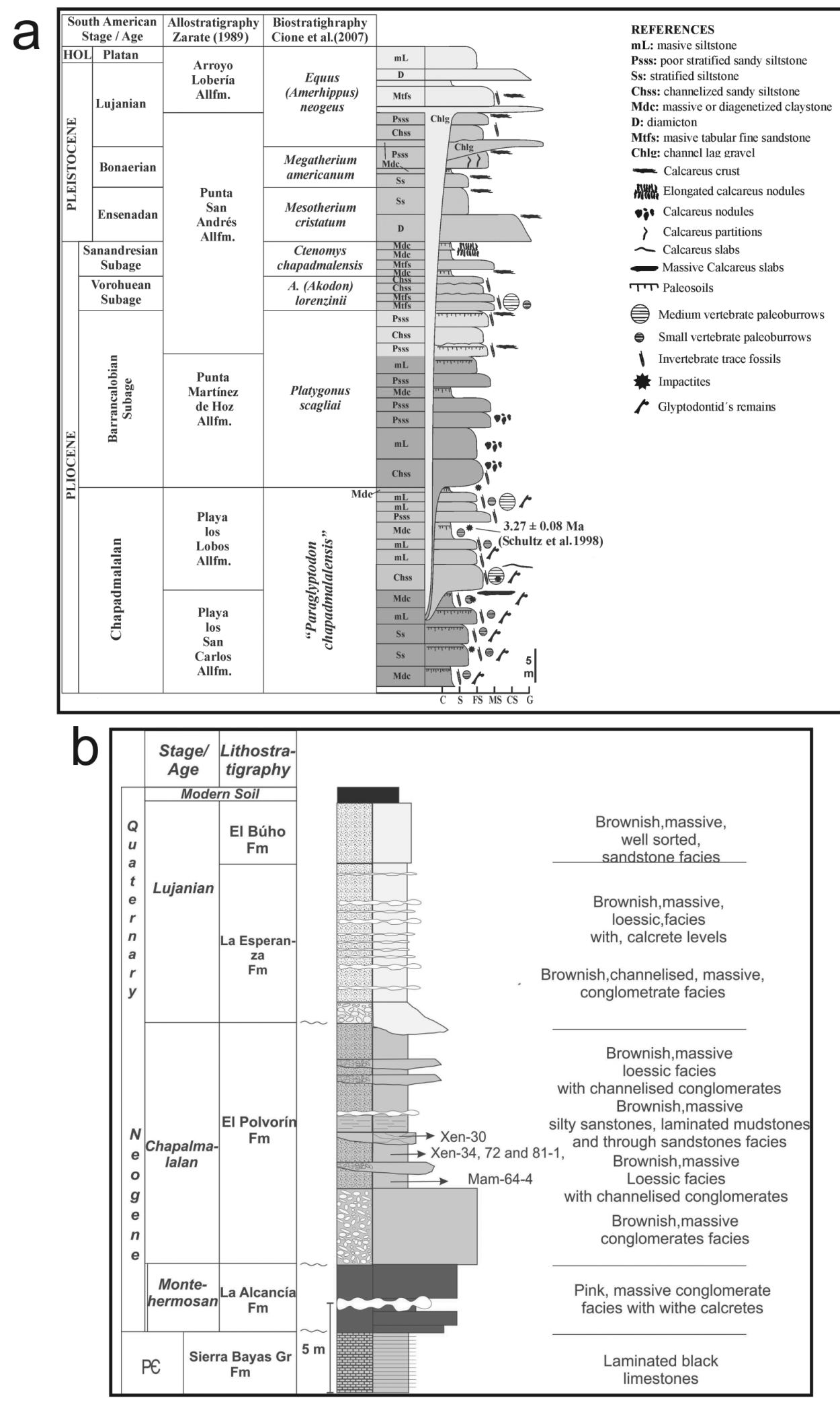

Figure 2 - Lithostratigraphic profile of Chapadmalal (a) and El Polvorín (b) formations showing the fossiliferous levels. 
Ameghino", Mercedes, Buenos Aires, Argentina; MFCA: Museo Universitario "Florentino y Carlos Ameghino", Universidad Nacional de Rosario (ex Instituto de Fisiografía y Geología “Alfredo Castellanos"), Rosario, Santa Fe, Argentina; MNPA-V: Museo Nacional PaleontológicoArqueológico (Vertebrados) Tarija, Bolivia; MMP: Museo Municipal de Ciencias Naturales "Lorenzo Scaglia", Mar del Plata, Buenos Aires, Argentina; PVE-F: Colección Paleontológica del Museo de Ciencias Naturales de Formosa, Villa Escolar, Formosa, Argentina; Xen, Colección "Cementos Avellaneda", Olavarría, Buenos Aires, Argentina.

Other abbreviations:

cf: central figure; cs: central sulcus; rs: radial sulci; rf: radiating foramina; pf: peripheral figures.

\section{SYSTEMATIC PALEONTOLOGY}

Magnorder Xenarthra Cope, 1889

Order Cingulata Illiger, 1811

Suborder Glyptodontia Gray, 1869 (nom. transl. Ameghino, 1889)

Family Glyptodontidae Gray, 1869

Tribe "Neuryurini” Hofstetter, 1958

Genus Urotherium Castellanos, 1926

\section{STRATIGRAPHIC AND GEOGRAPHIC DISTRIBUTION}

Late Miocene-Pliocene (“Araucanian”, "Mesopotamian", Montehermosan, Chapadmalalan and Marplatan ages) from the Pampean, Northwestern and Mesopotamian regions of Argentina (Castellanos 1926, 1948, Scillato-Yané et al. 1995, Carlini and Scillato-Yané 1999, Reguero et al. 2007, Reguero and Candela 2011).

REFERRED SPECIES

U. simplex Castellanos, 1926 (*type species)

U. interundatum (Ameghino, 1885) Castellanos, 1926

U. simile Castellanos, 1948

U. antiquum (Ameghino, 1888)

\section{TAXONOMIC AND ANATOMIC REMARKS}

Urotherium is a genus recognized by Castellanos (1926), which, according to Mones (1986a), includes three species: $U$. simplex, $U$. simile (Castellanos, 1948), and U. interundatum (Ameghino, 1885). In addition, Ameghino (1888) recognized a fourth species coming from the Monte Hermoso Formation, $U$. antiquus (=Neuryurus antiquus).

$U$. simplex (the type species) was described and characterized by Castellanos (1926) on the basis of a partial caudal tube (MACN Pv 5813) (Fig. $3 a)$, originally collected by Carlos and Florentino Ameghino in the surroundings of Chapadmalal, Buenos Aires province, Argentina, in 1908. In the same contribution, Castellanos (1926: 268) tentatively assigned five osteoderms of the dorsal carapace (MACN Pv 6288) (formerly assigned by F. Ameghino to "Sclerocalyptus sp?") originally interpreted by the same author as belonging to the genus Lomaphorus (see Castellanos, 1926: 268). The main characteristics mentioned for $U$. simplex include some morphological details of the exposed surface of the osteoderms of the caudal tube and dorsal carapace, which are clearly rugose and uniformly perforated by numerous small foramina, showing some resemblance to that observed in the Pleistocene genus Neuryurus (Zurita et al. 2006). In some osteoderms, it is possible to observe a central figure surrounded by a series of small radiating foramina. The contact area and articulation between adjacent osteoderms is evident and, in some cases, the osteoderms are not firmly united, a characteristic that is present in some juvenile specimens of Eosclerocalyptus C. Ameghino and Neosclerocalyptus Paula Couto (see Zurita 2007b). According to Castellanos (1926: 269), the caudal tube shows only one distal lateral figure on each side. The reexamination of the holotype indicates that the caudal tube is mostly restored, and thus its real morphology is difficult to observe. Furthermore, a comparison with new and more 

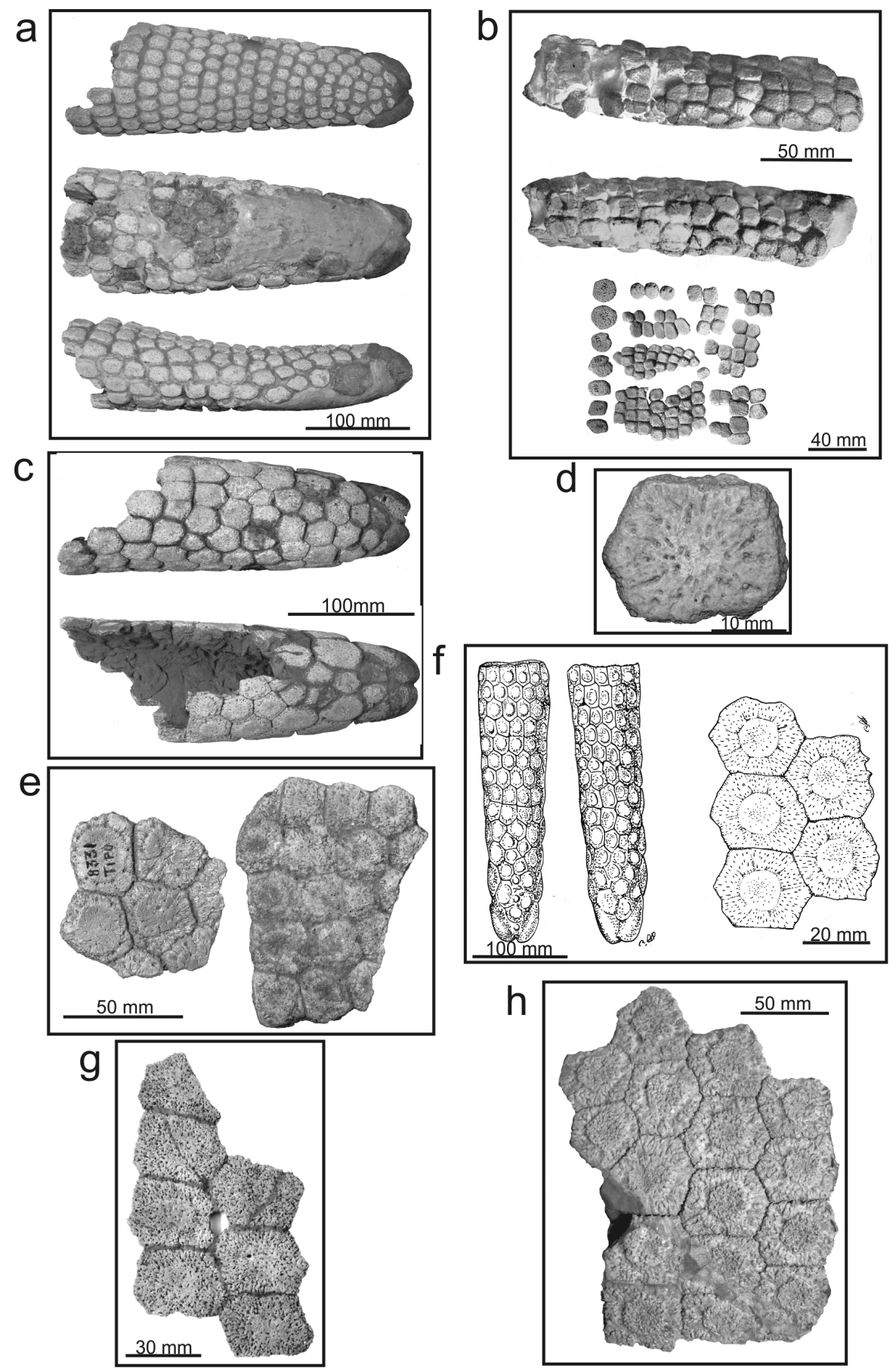

Figure 3 - a, Urotherium simplex (MACN Pv 5813 holotype), restored caudal tube in dorsal, ventral and lateral views; b, Urotherium simile, restored caudal tube in ventral and dorsal views (MFCA 727 holotype), associated osteoderms of the dorsal carapace (MFCA 593); c, Lomaphorus chapadmalensis (MACN Pv 5806 holotype), distal portion of caudal tube in ventral and dorsal views; d, Lomaphorus cingulatus (MACN A-592 calcotype), osteoderm of the dorsal carapace; e, Lomaphorops corallinus (MACN Pv 8331 holotype) associated osteoderms of the antero-lateral region of the dorsal carapace; $\mathbf{f}$, Lomaphorus imperfectus (modified from Ameghino, 1889, plate 58, figs. 1 and 3), caudal tube in dorsal and ventral views and associated osteoderms of the dorsal carapace; g, Trachycalyptus chapadmalensis (MACN Pv 5823 holotype), 7 associated osteoderms of the lateral region of the dorsal carapace; h, Paraglyptodon chapadmalensis (MACN Pv 6162 holotype), 16 assocciated osteoderms of the lateral region of the dorsal carapace. 
complete materials exhumed from the El Polvorín and Chapadmalal Formations, in addition to materials from "Araucanian" levels (late MiocenePliocene) of Northwestern Argentina, undoubtedly indicates that the main characteristics proposed for Urotherium are also present in some caudal tubes and dorsal carapaces of already well known taxa, especially in Eosclerocalyptus (Xen 30, Mam-63, MMP 4842, MFCA 676) and Plohophorus figuratus Ameghino(MMP 4823; Xen 72) (Figs. 4a, a',b, b',c). The particular morphology characterizing the referred specimens of Urotherium is produced by a taphonomic alteration at the level of the exposed surface of the osteoderms (Fig. 4b' and 5). Our observations show that this non-real pattern is mainly observable in the lineages of glyptodonts with "rosette" ornamentation (e.g. Plohophorus and Eosclerocalyptus). In addition, the presence of only one lateral figure on each side of the caudal tube (mentioned as a diagnostic characteristic of $U$. simplex) is also shared by other related glyptodonts such as the Neosclerocalyptini Neosclerocalyptus (Zurita 2007a). On the other hand, the linear measurements given by Castellanos (1926: 263) are within the ranges of Eosclerocalyptus and Neosclerocalyptus (see Zurita 2007a). In summary, new specimens preserving dorsal carapaces and/or caudal tubes and showing the two types of ornamentation (i.e. "Urotherium" and Eosclerocalyptus patterns) are quite common in Pliocene levels (Figs. 4a, a',a" and 5d). Notably, and supporting our taxonomic hypothesis, none of the materials referred to Pliocene Urotherium include the skull (except $U$. antiquus, a species coming from the Monte Hermoso Formation, see below). This is because, when the skull is found associated with the dorsal carapace, the specimen is assigned to already known taxa, like Eosclerocalyptus and Plohophorus.

Although it is not the main purpose of this contribution, the revision of the holotype of $U$. simile (MFCA 727), a species recognized by
Castellanos (1948) from "Araucanian" levels (late Miocene-early Pliocene) in Santa María, Valle de Yocavil, Catamarca province, Argentina, indicates that it corresponds to a juvenile specimen, a situation observed by Castellanos himself (1948: 6). The materials include a very badly preserved caudal tube, a large number of non-articulated osteoderms, and a fragment of the right hemimandible with two molariforms (MFCA 593) (Fig. 3b). The morphology of these structures completely coincides with that of a juvenile glyptodont (Fig. 4d,f), as observed in Zurita (2007b) (e.g. MFCA 676) and Zurita et al. (2009, 2011c) (e.g. PVE-F 85 and MNAP-V 6146a) and thus shows no diagnostic characteristic. In fact, the almost only characteristic mentioned by Castellanos (1948) to identify this species (i.e. the smaller size of the caudal tube compared to $U$. simplex) could correspond to the early ontogenetic stage of this specimen.

With regard to $U$. interundatum, the holotype is currently lost (MCNP-; see Mones 1986a, ScillatoYané et al. 2013) but a calcotype is preserved (MLP M-229). As pointed out by Scillato-Yané et al. (2013), the fossil is restricted to a single osteoderm of the dorsal carapace. Although some characteristics suggest a Doedicurinae resemblance, the scarcity and bad state of preservation of the osteoderm precludes any taxonomic hypothesis, and more material is needed.

As mentioned above, the only species in which the skull is preserved corresponds to U. antiquum (=Neuryurus antiquus), a species recognized by Ameghino (1888) from the Monte Hermoso Formation that requires an urgent taxonomic revision. In addition to associated osteoderms, this taxon includes the dorsal carapace, a relatively well preserved skull and a left hemimandible. However, an examination of the referred materials (Ameghino 1889, Plate LXII, Figs. 6 and 7) indicates two different types of osteoderms that can not belong to the same species: one of them shows a typical Doedicurinae affinity (see Zurita et al. 2014) while 


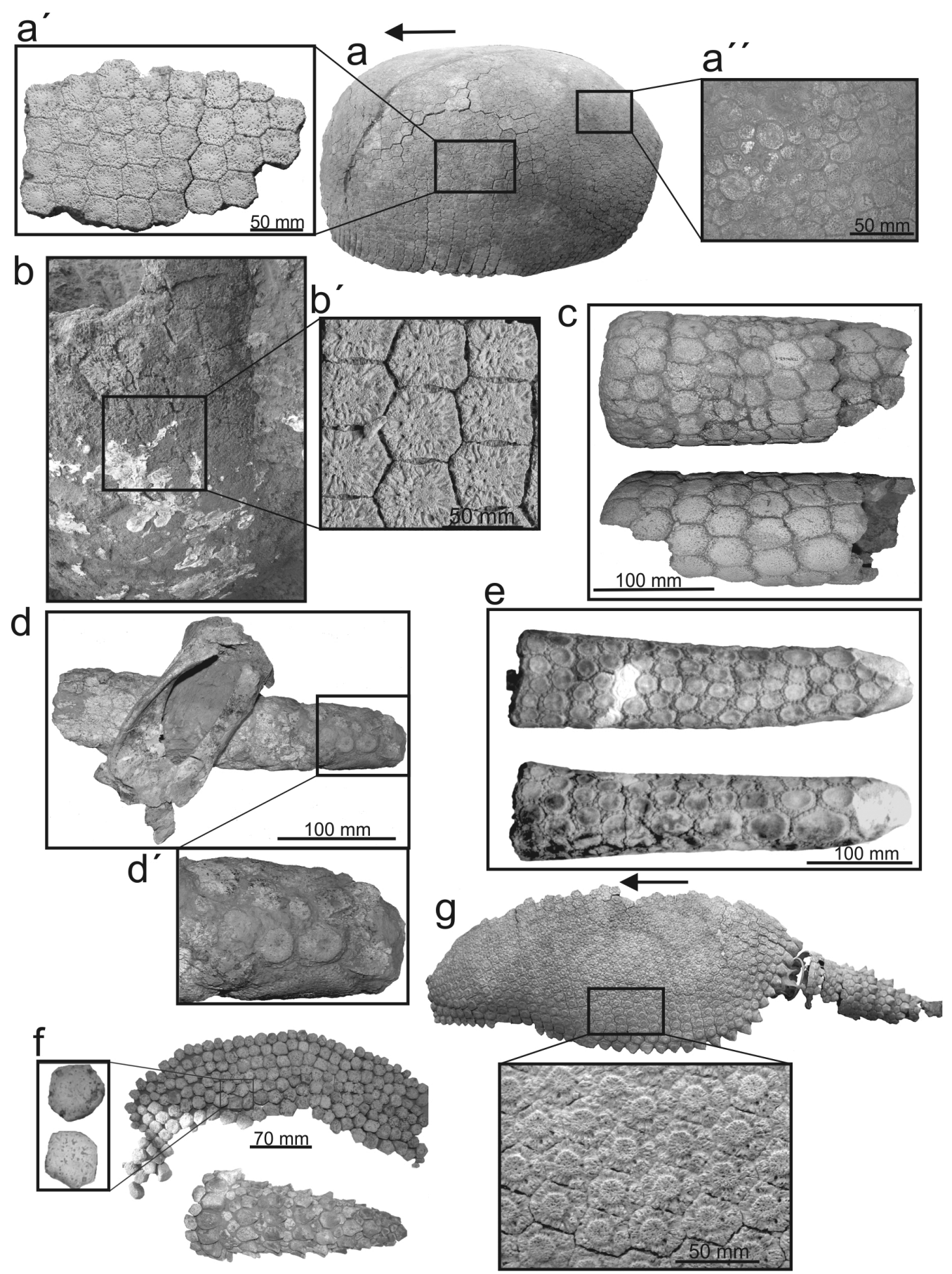

Figure 4 - Eosclerocalyptus cf. lineatus (Xen 30). a, dorsal carapace in lateral view; a', detail of the exposed surface of the osteoderms showing a clear Lomaphorus/Urotherium/Trachycalyptus ornamentation pattern; a", detail of the exposed surface of the osteoderms showing a "rosette" ornamentation pattern; b, Eosclerocalyptus sp., dorsal carapace showing the taphonomic alteration of its exposed surface (b'); c, Eosclerocalyptus cf. lineatus (Xen 30), proximal half of caudal tube showing a Lomaphorus/ Urotherium pattern; d, Neosclerocalyptus (GCF 83), caudal tube belonging to a juvenile specimen; d', detail of the distal portion showing the particular morphology; e, Neosclerocalyptus ornatus (MMP 4600), caudal tube in dorsal and ventral views showing the similitude with the caudal tube assigned to Lomaphorus; f, Glyptodon (PVF 85), associated osteoderms and caudal armor belonging to an early juvenile stage; g, Glyptodon reticulatus (MCA 2017), dorsal carapace belonging to a juvenile specimen showing the morphology of the lateral osteoderms. 




Figure 5 - Eosclerocalyptus. a (MMP 5303)-b (Xen 30). Osteoderms from the lateral region of the dorsal carapace showing the taphonomic alteration in the exposed exposed (=Lomaphorus/ Urotherium/Trachychalyptus pattern); c (FM 05-266), lateral osteoderms showing the "rosette" ornamentation pattern; d, Eosclerocalyptus (Xen 30), detail of the lateral region of the dorsal carapace showing the alteration, from a real ornamentation pattern to a Urotherium/Lomaphorus/ Trachycalyptus pattern.

the other shows a more similar condition observed in the "Urotherium pattern". This situation suggests that the material could include more than one specimen. With regard to the skull referred by Ameghino (1889, Plate LXIII), although preliminary, a comparison with a Pliocene Doedicurinae recently described in Zurita et al. (2014), suggests that $U$. antiquum does not show a Doedicurinae morphology.

Tribe "Lomaphorini" Hoffstetter, 1958

Genus Lomaphorus Ameghino, 1889

\section{STRATIGRAPHIC AND GEOGRAPHIC DISTRIBUTION}

Late Miocene-Pleistocene of the Pampean and Mesopotamian regions of Argentina, Pleistocene of Uruguay (Mones and Francis 1973, ScillatoYané et al. 1995, Carlini and Scillato-Yané 1999, Scillato-Yané et al. 2013).

\section{REFERRED SPECIES}

Lomaphorus imperfectus (Gervais and Ameghino, 1880) (*type species)

L. elevatus (Nodot, 1857)

L. compressus Ameghino, 1882

L. elegans (Burmeister, 1871)

L. cingulatus Ameghino, 1889

L. chapalmalensis Ameghino, 1908

TAXONOMIC AND ANATOMIC REMARKS

Lomaphorus is a genus created by Ameghino (1889) to originally include six species, of which one, Lomaphorus chapalmalensis Ameghino, 1908, is from the Chapadmalal Formation. From a morphological point of view, Ameghino (1889: 819 ), as was common at the time, characterized this genus on the basis of the exposed surface of 
the osteoderms of the dorsal carapace and some morphological details of the caudal tube. Among these morphological details, the exposed surface of the osteoderms presents a "rosette" pattern, although less noticeable than in "Hoplophorus" (i.e. Neosclerocalyptus Paula Couto), and in some cases the osteoderms are not firmly united among them, a characteristic also observed in Urotherium. In addition, it is possible to observe some radiating foramina surrounding this central figure, replacing the peripheral figures present in Eosclerocalyptus and Neosclerocalyptus. The general morphology of the caudal tube resembles that of Neosclerocalyptus, but the central figures of each osteoderm lack peripheral figures (Ameghino 1895: 327). Remarkably, Ameghino (1889: 819) noted that the species of Lomaphorus were smaller than those of "Hoplophorus" (=Neosclerocalyptus). This is an important observation, because several of the characteristics postulated by Ameghino agree with those described for juvenile specimens of Neosclerocalyptus (Zurita et al. 2005; e.g. GCF 83) and Eosclerocalyptus (Zurita 2007b; e.g. MFCA 676) (Fig. 4d), and even for other clades such as Glyptodontinae (Zurita et al. 2011c). In fact, the assignment of this particular morphology to juvenile specimens was first mentioned by Lydekker (1895: 21), supporting his idea that the caudal tube of Lomaphorus corresponded in fact to "Sclerocalyptus" (i.e. Neosclerocalyptus). This taxonomic and ontogenetic interpretation was rejected by Ameghino (1895). However, it seems probable that Ameghino himself had doubts about the validity of Lomaphorus when he stated that: "In my opinion, this is the name that should continue to be used, even if it were proven that Lomaphorus is not a distinct genus" (Ameghino 1895: 525).

In this scenario, Lomaphorus chapalmalensis was created by Ameghino (1908) on the basis of a distal fragment of the caudal tube (MACN Pv 5806) (Fig. 3c). As observed in U. simplex, the main characteristics correspond to a particular morphology of the exposed surface of the osteoderms. This is mainly rugose with a variable number of small foramina. In dorsal view, in some osteoderms it is possible to observe an elevated central figure, which is surrounded by a large number of small radiating foramina. This morphology completely agrees with that observed for several specimens of Eosclerocalyptus exhumed from the El Polvorín and Chapadmalal Formations (e.g. Mam-63-4) (Fig. 4c). Actually, this morphology was also observed in some juvenile specimens of the Pleistocene and Pliocene genera Neosclerocalyptus (e.g. GCF 83) and Eosclerocalyptus (e.g. MFCA 676) (Fig. 4d,d'). Our observations, including those of complete specimens of Neosclerocalyptus and Eosclerocalyptus (e.g. Xen 30; MMP 5303), show that some areas of the dorsal carapace show a typical "Lomaphorus" ornamentation pattern whereas others preserve the real "rosette" ornamentation pattern (Figs. 3 a,a'a" and 5d).

In the remaining species of the genus, particularly in L. cingulatus Ameghino 1889, the single osteoderm from the dorsal carapace (Fig. $3 \mathrm{~d}$ ), which characterizes the species and comes from the "Mesopotamian" (late Miocene-early Pliocene) of the surroundings of Paraná, Entre Ríos province, is currently lost. However, there is a calcotype (MACN A-592). According to Castellanos (1940: 262) and Scillato-Yané et al. (2013: 125), this osteoderm does not correspond to the genus Lomaphorus (Trachycalyptus?). In fact, the characteristics postulated by Ameghino (1889: 821) agree with those of the remaining species of Lomaphorus, and the scarcity of the material precludes a precise taxonomic assignation, indicating that this species must be labeled as nomen dubium.

Lomaphorus corallinus is another species recognized and characterized by Rovereto (1914: 103, Plate VII, fig. 1, 1a) on the basis of some associated osteoderms of the dorsal carapace (MACN Pv 8331) (Fig. 3e). The holotype comes from "Arau- 
canian" levels (late Miocene-Pliocene) of northwestern Argentina (Valle de Santa María, Catamarca province). Later, this species was transferred by Castellanos (1932) to the genus Lomaphorops, although this was rejected by Cabrera (1944) due to the scarcity of the holotype and the lack of characteristics. Castellanos (1948) later referred to this species new material, particularly numerous osteoderms of the dorsal carapace and a caudal tube. The holotype corresponds to osteoderms of the antero-lateral region of the dorsal carapace, and their exposed surface is almost identical to that observed in glyptodonts with a "rosette" ornamentation pattern. In fact, Castellanos himself (1948: 8) indicated that some osteoderms were very similar to those of Trachycalyptus, whereas others were similar to those of Eosclerocalyptus and Neosclerocalyptus. Therefore, no diagnostic characteristics are visible, and this species must be considered as nomen dubium (sensu Mones 1986b). In addition, the original description given by Rovereto (1914) completely agrees with the morphology of the exposed surface of the osteoderms of the antero-lateral region of the dorsal carapace of glyptodonts with a "rosette" ornamentation pattern (e.g. Eosclerocalyptus).

The Pleistocene species of Lomaphorus correspond to L. imperfectus (Gervais and Ameghino, 1880 , the type species of the genus), L. compressus Ameghino, 1882, L. elegans Burmeister, and L. gracilis Nodot, 1857. Lomaphorus has been mentioned as a valid taxon in the early Pleistocene (Ensenadan Age) and middle Pleistocene (Bonaerian Age) of the Pampean region of Argentina (Ameghino 1889, Scillato-Yané et al. 1995, Carlini and Scillato-Yané 1999, Cione and Tonni 2005, Soibelzon et al. 2010, Luna and Giraudo 2012, Cruz et al. 2012). L. imperfectus is mainly known on the basis of osteoderms of the dorsal carapace and caudal tubes. Even if the holotype is not known with certainty, some material was illustrated by Ameghino (1889, Plate 58, fig. 1,
2, 3 and Plate 60, fig. 6) and Lydekker (1895, Plate 3, fig. 1) (Fig. 3f). Our comparisons with specimens of Neosclerocalyptus pseudornatus and N. ornatus including both structures (e.g. MMP 4600, MACN Pv 7075; Fig. 4d,e) show a remarkable morphological similarity (see Zurita 2007a). L. compressus is only known by osteoderms of the dorsal carapace (see Ameghino, 1889, Plate 69, fig. 18). As in the previous case, the morphology of the exposed surface of the osteoderms is also present in several specimens of Neosclerocalyptus (e.g. MFCA 758). The poor characterization of this species becomes evident when Ameghino (1895) stated that: "Sclerocalyptus scrobiculatus should disappear because the armor attributed to this species belongs to Lomaphorus compressus..." In turn, the morphology of the osteoderms of L. elevatus clearly resembles that of juvenile specimens of Neosclerocalyptus, as pointed out by Luna and Giraudo (2012) and Oliva et al. (2013). Supporting this interpretation, none of the remains assigned to Lomaphorus included the skull.

Genus Trachycalyptus Ameghino in Rovereto (1914)

\section{STRATIGRAPHIC AND GEOGRAPHIC DISTRIBUTION}

Late Miocene-Pliocene of Argentina.

\section{REFERRED SPECIES}

T. chapadmalensis Ameghino in Rovereto (1914)

TAXONOMIC AND ANATOMIC REMARKS

Trachycalyptus is another poorly characterized genus, originally recognized by Ameghino (1908) as a nomen nudum and later illustrated by Rovereto (1914 Plate 27, fig. 2). T. chapadmalensis is a species that has never been formally described. The holotype (MACN Pv 5823) comprises seven associated osteoderms of the lateral region of the dorsal carapace, possibly from the Chapadmalal Formation (Fig. 3g). Reexamination of the material has shown that the osteoderms only preserved 
the outer zone (see Krmpotic et al. 2009). The genus was characterized by Castellanos in several opportunities (e.g. Castellanos 1940: 263, 1948: 11). As in the above-mentioned genera, the main diagnostic characteristic completely agrees with that of glyptodonts possessing a "rosette" pattern at the level of the dorsal carapace, and the morphology is almost identical to that observed in the specimens referred to Lomaphorus and Urotherium.

Subfamily Glyptodontinae Gray, 1869

Genus Paraglyptodon Castellanos, 1932

\section{STRATIGRAPHIC AND GEOGRAPHIC DISTRIBUTION}

Pliocene of the Pampean and Northwestern regions of Argentina (Ameghino 1908, Castellanos 1953, Reguero et al. 2007, Reguero and Candela 2011, Zurita et al. 2013).

\section{REFERRED SPECIES}

P. chapadmalensis (Ameghino, 1908)

P. dubius (Ameghino, 1908)

P. uquiensis Castellanos, 1953

P. paranensis Castellanos, 1953

TAXONOMIC AND ANATOMIC REMARKS

Two species of the subfamily Glyptodontinae were recognized as originally coming from the Chapadmalal Formation: P. dubius Castellanos and P. chapadmalensis (Ameghino in Rovereto). The latter species was originally recognized by Ameghino (1908: 426) as belonging to the Pleistocene genus Glyptodon Owen (G. chapadmalensis) but neither illustrated nor descriptions were available in that contribution. Some years later, Rovereto (1914: Plate 27) illustrated the holotype and classified it as "Sclerocalyptus" chapadmalensis (Fig. 3H). In turn, Castellanos (1932) recognized the genus Paraglyptodon to include this species ( $P$. chapadmalensis). Some years later Castellanos (1953) included two articulated osteoderms (MACN Pv 6285), previously illustrated by Rovereto (1914, Plate 29) with the same stratigraphic and geographic provenance as $P$. chapadmalensis, as $P$. dubius. As pointed by Oliva et al. (2010) both holotypes ( $P$. chapadmalensis and $P$. dubius) are morphologically almost identical and undoubtedly correspond to the subfamily Glyptodontinae, taking into account the morphology of their exposed surface (see Zurita et al. 2013). However, a new revision of the holotype of $P$. chapadmalensis and $P$. dubius demonstrates that it is not possible to observe clear diagnostic characteristics. This is mainly because the 16 associated osteoderms forming the holotype of P. chapadmalensis (Fig. 3h) correspond to the lateral region of the dorsal carapace, which retains a conservative morphology in most glyptodonts (see Zurita et al. 2011b, 2013). Our observations suggest that the exposed surface of the osteoderms presents the same taphonomic alteration observed in other glyptodonts with "rosette" ornamentation pattern. In addition to this, it seems possible that the osteoderms do not come from Pliocene sediments but from upper Pleistocene units (MT per. obs., see also Reig 1958). This possibility is congruent with the original observations of Ameghino (1908), who identified the osteoderms as belonging to Glyptodon. In fact, comparisons with juvenile specimens of Glyptodon suggest that the holotype represents an early ontogenetic stage of Glyptodon (Zurita et al. 2011c) (Fig. 4g). This is an important observation because $P$. chapadmalensis characterizes the upper Chapadmalalan Age/Stage (see Cione and Tonni 2005). According to this, the only valid species of the genus corresponds to P. uquiensis Castellanos, a well characterized species that shows several synapomorphies with Glyptodon (Zurita et al. 2013). In turn, Oliva et al. (2010) demonstrated the status of nomen dubium of P. paranensis.

\section{DISCUSSION AND RESULTS}

A large diversity of Cingulata Glyptodontidae has been traditionally proposed as characterizing the Pliocene, especially the Chapadmalalan Age/Stage 
(late Pliocene). As common during the second half of the 19th century and the first half of the 20th century, these taxa were mainly recognized on the basis of partial dorsal carapace and/or caudal tubes (Soibelzon et al. 2006, Fernicola and Porpino 2012). Since then, this diversity has been regarded as valid in most of the specialized literature (see Pascual et al. 1966, Scillato-Yané et al. 1995, Carlini and Scillato-Yané 1999, Cione and Tonni 1995, 2001, 2005, among others).

In this context, both the reexamination of the holotypes and new findings coming from Chapadmalal and El Polvorín Formations indicate that the real diversity of Glyptodontidae of the Pliocene (and some of the Pleistocene) is much more restricted than previously considered. The particular pattern observed in the exposed surface of the osteoderms of the dorsal carapace and/or caudal tube characterizing several taxa, is due to a taphonomic alteration and/or juvenile specimens (see Zurita et al. 2009, 2011c). Although this non-real pattern can be observed in some Pleistocene specimens, this taphonomic process is very common in late Pliocene glyptodonts. To support our hypothesis, it is possible to mention the following: a) none of these taxa include skulls; b) in several taxa, the description given by the authors includes an intriguing combination of characteristics present in well known species (e.g. Neosclerocalyptus and Eosclerocalyptus) with others produced by this taphonomic alteration; c) on several occasions, the authors themselves recognized the notable morphological similarity among taxa ("Lomaphorops", Trachycalyptus and Lomaphorus....... although they present similarities that relate them closely"; Castellanos 1948: 26); d) the notable similarity between Lomaphorus and "Sclerocalyptus" (=Neosclerocalyptus) becomes evident when Ameghino himself transferred some material originally assigned to Lomaphorus to "Sclerocalyptus" (Ameghino 1889) or by the endless debate between Ameghino (1895) and
Lydekker (1895) about the taxonomic identity of Lomaphorus and "Sclerocalyptus".

In addition, the strongest argument concerns the new findings from the Chapadmalal and El Polvorín Formations of almost complete specimens of well known species (Eosclerocalyptus and Plohophorus), in which some areas of the dorsal carapace/caudal tubes presenta typicalLomaphorus/ Trachycalyptus/Urotherium morphology while others present a clear "rosette" pattern (Fig. 5).

From a biostratigraphic point of view, some species were important. This is especially true for the Glyptodontinae Paraglyptodon chapadmalensis, because it characterizes the upper Chapadmalalan Age/Stage (see Cione and Tonni 1995, 2005). In fact, with regard to the Glyptodontinae, our field observations show the almost complete absence of records of this clade in Chapadmalalan levels, a situation that dramatically changes when compared to the Pleistocene, in which Glyptodontinae become the most abundant glyptodonts in South America (Carlini and Zurita 2010). Suggestively, the Glyptodontinae seem to be more frequently recorded in the late Chapadmalalan levels of Uquía Formation (Northwestern Argentina). This could be due to the fact that both regions have had different biogeographical scenarios since late Miocene (see Reguero et al. 2007, Reguero and Candela 2011).

In this context, the Glyptodontidae "Plohophorini" were not formally studied in this contribution, but all the remains recovered from the Chapadmalal and El Polvorín Formations belong to Plohophorus figuratus, a taxon also present in the Monte Hermoso Formation (Tomassini et al. 2013). It is possible that the remaining species of Plohophorus with the same stratigraphic and geographic provenance and recognized on the basis of caudal tubes ( $P$. cuneiformis Ameghino, $P$. coronatus Rovereto, and P. sygmaturus Ameghino) (see Castellanos 1939) constitute junior synonyms of $P$. figuratus. This is an important point, because Deschamps (2005) proposed the Actenomys priscus-P. 
cuneiformis zone. An integral taxonomic revision of Plohophorus and allied genera is thus needed. With regard the Glypodontidae Doedicurinae, Zurita et al. (2014) recently suggested the presence of cf. Eleutherocercus antiquus as the only valid species coming from Chapadmalalan levels.

From a biostratigraphic point of view, the Glyptodontidae assemblage recognized both for the El Polvorín and the Chapadmalal Formations clearly suggests that both units are, at least partially, synchronous. This interpretation is in agreement with the age estimated for El Polvorín ( $c a .3 .55$ Ma) and Chapadmalal Formations (ca. 4.5-3.2 Ma.) (see Zárate 2005, Gómez Samus et al. 2014).

\section{CONCLUSIONS}

The evidence indicates that the real diversity of Pliocene Glyptodontidae is much more limited than previously supposed, as already proven in some Pleistocene glyptodonts. In fact, most of the species included in the genera Lomaphorus, Lomaphorops, Urotherium, and Trachycalyptus chapadmalensis do not show valid characteristics and must thus be considered as non-valid taxa. From a biostratigraphic perspective, the Glyptodontinae P. chapadmalensis does not show an adequate characterization and must be replaced as a fossil guide in the biozone of the Upper Chapadmalalan Age/Stage.

Taking into account the real diversity of late Pliocene Glyptodontidae, the scarcity of records of Glyptodontinae draws attention, whereas the Doedicurinae (cf. Eleutherocercus antiquus), Eosclerocalyptus and "Plohophorini" (Plohophorus figuratus) are the most frequently recorded taxa in the Chapadmalal and El Polvorín Formations (Table I). This situation clearly contrasts with the Pleistocene scenario, in which the "Plohophorini" are completely absent, the Doedicurinae are one of the least recorded glyptodonts, and the Glyptodontinae (Glyptodon and Glyptotherium) are the glyptodonts most frequently recorded (Carlini and Zurita 2010). The evidence suggests that this turnover regarding the Glyptodontidae association started between the older Chapadmalalan and the younger Marplatan (ca.3.3 Ma; see Cione and Tonni 2001, Vizcaíno et al. 2004). However, taking into account the results presented in this contribution, an update of the Marplatan Glyptodontidae is much needed.

Finally, a preliminary comparison between the Glyptodontidae association from the Montehermosan levels of the Monte Hermoso Formation (late Miocene?-Pliocene) and Chapadmalalan levels, suggests that it is certainly possible that most of the valid taxa are present in both units, as recently suggested by Zurita et al. (2014). This observation is in agreement (at least in part) with the hypothesis of Tomassini et al. (2013) with regard to the real age of the Monte Hermoso Formation and its chronological relation with the Chapadmalal Formation.

TABLE I

Table showing the real diversity of Chapadmalalan (Pliocene) Cingulata Glyptodontidae.

\section{Diversity of Chapadmalalan (Pliocene) Glyptodontidae}

\begin{tabular}{|l|l|}
\hline \multicolumn{1}{|c|}{ Before this study } & \multicolumn{1}{|c|}{ After this study } \\
\hline Paraglyptodon chapadmalensis & Glyptodontinae incertae sedis \\
Trachycalyptus chapadmalensis & cf. Eleutherocercus antiquus \\
Urotherium simplex & Eosclerocalyptus cf. lineatus \\
Lomaphorus chapalmalensis & Plohophorus figuratus \\
Palaeodaedicurus? chapadmalensis & \\
\hline
\end{tabular}




\section{RESUMO}

A idade Chapadmalalan (Plioceno) é caracterizada por uma grande diversidade dos Glyptodontidae. A maioria dos táxons é reconhecida a partir de carapaças dorsais parciais e/ou tubos caudais, enquanto que as principais características diagnósticas estão relacionadas com a morfologia particular das superfícies expostas dos osteodermas. Algumas espécies são importantes sob o ponto de vista biogeográfico. O Chapadmalalan Superior é baseado na biozona de Paraglyptodon chapadmalensis. Uma reavaliação do material tipo e referido, aliado a novos achados procedentes das formações Chapadmalal e El Polvorín, indica que a diversidade de Glyptodontidae é menor do que se supunha. A morfologia particular das superfícies expostas dos osteodermas utilizada para a caracterização de algumas espécies na realidade se deve a alterações tafonômicas, que resultaram em um padrão de ornamentação não real. Assim, o Glytodontinae $P$. chapadmalensis deve ser substituído como fóssil guia, uma vez que nem essa espécie nem as incluídas nos gêneros Urotherium, Trachycalyptus e Lomaphorus são bem caracterizadas. Levando-se em conta a diversidade dos Glyptodontidae para esse intervalo, os Glyptodontinae são muito raros (contrastando com a sua abundância no Pleistoceno), enquanto que Eosclerocalyptus, "Plohophorini" (Plohophorus) e Doedicurinae (cf. Eleutherocercus antiquus) são os táxons mais registrados.

Palavras-chave: Diversidade, Glyotodontes, Osteodermas, Plioceno, Sul da América do Sul.

\section{ACKNOWLEDGMENTS}

We thank 'Cementos Avellaneda' and the staff at the Museo Municipal de Ciencias Naturales de Mar del Plata 'Lorenzo Scaglia' for allowing the study of material under their care. This contribution was partially supported by grants PIP 0150 (CONICET) and PI Q 001/13 (SGCyT-UNNE).

\section{REFERENCES}

Ameghino F. 1882. Catálogo de las colecciones de antropología prehistórica y de paleontología de Florentino Ameghino, partido de Mercedes. In: Catálogo de la Sección de la provincia de Buenos Aires (República Argentina), en la Exposición Continental Sudamericana. Anexo A, p. 3542

AMEGHino F. 1885. Nuevos restos de mamíferos fósiles oligocenos recogidos por el Profesor Pedro Scalabrini y pertenecientes al Museo Provincia de la ciudad de Paraná. Bol Acad Nac Cienc Córdoba 8: 5-207.

AMEGHINO F. 1888. Lista de las especies de mamíferos fósiles de Mioceno superior de Monte Hermoso, hasta ahora conocidas. Coni PE (Ed), Buenos Aires, 21 p.

AMEGHINO F. 1889. Contribución al conocimiento de los mamíferos fósiles de la República Argentina. Act Acad Nac Cienc Córdoba 6: 1-1027.

AMEGHINO F. 1895. Sur les édentés fossiles de 1' Argentine (Examen critique, révision et correction de l' ouvrage de M. R. Lydekker "The extinct Edentates of Argentina"). Rev J Zool Bs As 3: 97-192.

AMEGHINO F. 1908. Las formaciones sedimentarias de la región litoral de Mar del Plata y Chapalmalal. An Mus Nac Hist Nat Buenos Aires 9: 343-428.

BORRELLO AV. 1966. Trazas, restos tubiformes y cuerpos fósiles problemáticos de la Formación La Tinta, Sierras Septentrionales de la Provincia de Buenos Aires. Paleontografía Bonaerense 5, Comisión de Investigaciones Científicas, Provincia de Buenos Aires, La Plata.

BURMEISTER G. 1870-1874. Monografía de los Glyptodontes en el Museo Público de Buenos Aires. An Mus Pub Buenos Aires 2: 1-412.

CABRERA A. 1944. Los Gliptodontoideos del Araucaniano de Catamarca. Rev Mus La Plata 3(15): 5-76.

CARlini AA AND SCILlATO-YANÉ GJ. 1999. Evolution of Quaternary Xenarthrans (Mammalia) of Argentina. In: Rabassa J and Salemme M (Eds), Quaternary of South America and Antarctic Peninsula. A.A. Balkema, Rotterdam, p. 149-175.

CARLINI AA AND ZURITA AE. 2010. An Introduction to Cingulate Evolution and Their Evolutionary History during the Great American Biotic Interchange: Biogeographical Clues from Venezuela. In: Sánchez-Villagra et al. (Eds), Urumaco and Venezuelan Paleontology, Indiana University Press, USA, p. 233-255.

CARlini AA, ZuritA AE AND Aguilera O. 2008a. North American Glyptodontines (Xenarthra, Mammalia) in the Upper Pleistocene of Northern South America. Palaeontol Z 82: 139-152.

CARLINI AA, ZURITA AE AND SCILLATO-YANÉ GJ. 2008b. New glyptodont species from Codore Formation (Pliocene), Estado Falcón (Venezuela), and the 'Asterostemma' problem. Palaeontol Z 82: 125-138.

CASTEllanos A. 1926. Sobre un nuevo gliptodóntido chapadmalense. Urotherium simplex $n$. gen. $n$. sp. y las formas afines. An Mus Nac Hist Nat Buenos Aires 60: 263-278.

CASTEllanos A. 1932. Nuevos géneros de gliptodontes en relación con su filogenia. Physis 11(38): 92-100. 
Castellanos A. 1939. A propósito de los géneros Plohophorus, Nopachthus y Panochthus ( $1^{\circ}$ parte). Pub Inst Fisiogr Geol 6: 1-279.

Castellanos A. 1940. A propósito de los géneros Plohophorus, Nopachthus y Panochthus ( $2^{\circ}$ parte). Pub Inst Fisiogr Geol 8: 280-414.

CAstellanos A. 1941. A propósito de los géneros Plohophorus, Nopachthus y Panochthus ( $3^{\circ}$ parte). Pub Inst Fisiogr Geol 11: 420-583.

CASTELLANOS A. 1948. La presencia del género "Urotherium" en el "Araucanense" del Valle del Yocavil (Santa María), provincias de Catamarca y Tucumán. Pub Inst Fisiogr Geol 35: 1-16.

Castellanos A. 1953. Descripción de restos de Paraglyptodon uquiensis n. sp. de Uquía (Senador Pérez), Jujuy. Mem Mus Entre Ríos 32: 1-3.

CIONE AL AND TONNI EP. 1995. Bioestratigrafía y cronología del Cenozoico de la región Pampeana. In: Alberdi et al. (Eds), Evolución biológica y climática de la región Pampeana durante los últimos cinco millones de años. Un ensayo de correlación con el Mediterráneo occidental, Madrid: Museo Nacional de Ciencias Naturales, Consejo Superior de Investigaciones Científicas. Monografías CSIC 12: 47-74.

CIONE AL AND TONNI EP. 1996. Reassessment of the PlioPleistocene continental time scale of southern South America. Correlation of the type Chapadmalalan with Bolivian sections. J S Am Earth Sci 9: 221-226.

CIONE AL AND TONNI EP. 2001. Correlation of Pliocene to Holocene southern South American and European vertebrate-bearing units. Boll Soc Pal Ital 40: 167-173.

CIONE AL AND TONNI EP. 2005 Bioestratigrafía basada en mamíferos del Cenozoico Superior de la provincia de Buenos Aires, Argentina. $16^{\text {th }}$ Cong Geo Arg Relat, p. 183200.

CIONE AL ET AL. 2007. Mamíferos continentales del Mioceno tardío a la actualidad en la Argentina: cincuenta años de estudios. Ameghiniana 11: 257-278.

CRUZ LE, FERnícola JC, CARIGNANO CA AND BARGO S. 2012. Asociaciones faunísticas del Cuaternario de San Francisco, provincia de Córdoba, Argentina. Implicancias taxonómicas y bioestratigráficas. Ameghiniana 49: 642656.

De Los Reyes M, Poiré D, Soibelzon L, Zurita AE AND AROUY MJ. 2013. First evidence of scavenging in a Glyptodont (Mammalia, Glyptodontidae) from the Pliocene of the Pampean region (Argentina). Taphonomic and paleoecological remarks. Paleontol Electron 16(2) $15 \mathrm{~A} ; 13 \mathrm{p}$.

DESCHAMPS CM. 2005. Late Cenozoic mammal bio-chronostratigraphy in Southwestern Buenos Aires Province, Argentina. Ameghiniana 42: 733-750.

FERNICOLA JC. 2008. Nuevos aportes para la sistemática de los Glyptodontia Ameghino 1889 (Mammalia, Xenarthra, Cingulata). Ameghiniana 45: 553-574.
FERNICOLA JC AND PORPINO KO. 2012. Exoskeleton and Systematic: a historical Problem in the classification of Glyptodonts. J Mamm Evo 19(3): 171-183.

GERVAIS H AND AMEGHINO F. 1880. Los mamíferos fósiles de la América del Sur. Sabih e Igon. Paris-Buenos Aires, $25 \mathrm{p}$.

GILlETTE DD AND RAY CE. 1981. Glyptodonts of North America. Smithsonian Contrib Paleobiol 40: 1-251.

Gómez SAMUs ML, PoIRE D, BIDEGAIN JC, ARROUY J, DE LOS REYES M AND CANALICCHIO JM. 2014. Estudio paleomagnético preliminar en sedimentos de la Formación El Polvorín, Partido de Olavarría, Sistema de Tandilia. III Jornadas Paleontológicas del Centro, resúmenes, 15 p.

HoffsteTTER R. 1958. Xenarthra. In: Piveteau P (Ed), Traité de Paléontologie, Paris: Masson et Cie, Paris, France, p. 535-636.

KRAGLIEVICH L. 1934. La antigüedad pliocena de las faunas de Monte Hermoso y Chapadmalal, deducidas de su comparación con las que le precedieron y sucedieron. Imprenta El Siglo Estudiado. Montevideo, 132 p.

KRAGLIEVICH JL. 1952. El perfil geológico de Chapadmalal y Miramar, Provincia de Buenos Aires. Rev Mus Munic Cienc Nat Tradic Mar del Plata 1: 8-37.

KRMPOTIC CM, CIANCIO MR, BARBEITO C, MARIO RC AND CARLINI AA. 2009. Osteoderm morphology in recent and fossil euphractine xenarthrans. Acta Zool-Stockholm 90: 339-351.

LUNA C AND GIRAUDO H. 2012. Nuevos registros de Lomaphorus Ameghino, 1889 (Glyptodontidae, Hoplophorinae) en la provincia de Córdoba y consideraciones sobre la validez de L. elevatus (Nodot, 1857). Reunión Anual de Comunicaciones de la Asociación Paleontológica Argentina.

LYDEKKER R. 1895. Contribution to a knowledge of the fossil vertebrates of Argentina. 2. The extinct Edentates of Argentina. An Mus La Plata 3: 1-118.

MCKENNA MC AND BELL SK. 1997 Classification of Mammals. Above the Species Level. Columbia University Press. New York, $631 \mathrm{p}$.

MONES A. 1986a. Paleovertebrata Sudamericana. Catálogo sistemático de los vertebrados fósiles de América del Sur. Parte I. Lista preliminar y Bibliografía. Cour Forsch Senck 82: $1-625$.

MONES A. 1986b. Nomen Dubium vs. Nomen Vanum. J Vert Paleontol 9: 232-234.

MONES A AND FRANCIS JC. 1973. Lista de los vertebrados fósiles del Uruguay II. Com Pal Mus Hist Nat Montevideo 4: 39-98.

NÁGERA JJ. 1940. Tandilia. Biblioteca de la Facultad de Humanidades y Ciencias de la. Educación, Universidad Nacional de La Plata XXIV: 1-272.

NoDOT L. 1857. Description d' un nouveau genre d'édenté fossile renfermant plusieurs espèces voisines du Glyptodon, etc. Mém L' Acad Imp Scien, Arts et Belles-Lettres de Dijon 2: 1-170. 
OLIVA C, DONDAS A AND SCAGLIA F. 2013. Estudios preliminares sobre la ontogenia del género Neosclerocalyptus Paula Couto (Xenarthra, Glyptodontidae). Reunión Anual de Comunicaciones de la Asociación Paleontológica Argentina, resúmenes: 23. Córdoba.

OliVA C, ZURITA AE, DONDAS A AND SCILlato-YANÉ GJ. 2010. Los Glyptodontinae (Xenarthra, Glyptodontidae) del Piso/Edad Chapadmalalense (Plioceno tardío): revisión y aportes a su conocimiento. Rev Mex Cienc Geol 27: 112120.

ORGEIRA MJ. 1987. Estudio paleomagnético de sedimentos del Cenozoico tardío en la costa atlántica bonaerense. Rev Asoc Geol Arg 42(3-4): 362-376.

PASCUAL R, ORTEGA HINOJOSA EJ, GONDAR DG AND TONNI EP. 1966. Vertebrata. In: Borrello AV (Ed), Paleontografía Bonaerense. Vertebrata I. Comisión de Investigaciones Científicas de la provincia de Buenos Aires, 202 p.

Paula Couto C. 1979. Tratado de Paleomastozoologia. Academia Brasileira de Ciências, Rio de Janeiro, Brasil, $590 \mathrm{p}$.

POIRÉ DG. 1993. Estratigrafía del Precámbrico sedimentario de Olavarría, Sierras Bayas, provincia de Buenos Aires, Argentina. $13^{\circ}$ Congreso Geológico Argentino y $3^{\circ}$ Congreso de Exploración de Hidrocarburos, Actas 2:1-11.

POIRÉ DG. 2009. Estratigrafía de la cobertura sedimentaria Precámbrica/ Paleozoica inferior de las Sierras Septentrionales de la provincia de Buenos Aires (Sistema de Tandilia), Argentina. Centro de Investigaciones Geológicas, Argentina.

POIRÉ DG, CANALICCHIO JM, DE LOS REYES M AND PRADO JL. 2007. Estratigrafía de la cubierta Terciaria/ Cuaternaria del yacimiento El Polvorín, Olavarría, Sistema de Tandilia, Argentina. VI Jornadas Geológicas y Geofísicas Bonaerenses, resúmenes, $69 \mathrm{p}$.

PoIRÉ DG, CANESSA ND, SCILlATO-YANÉ GJ, CARLINI AA, CANALICCHIO JM AND TONNI EP. 2005. La Formación El Polvorín: una nueva unidad del Neógeno de Sierras Bayas, Sistema de Tandilia, Argentina. XVI Congreso Geológico Argentino, Actas. La Plata, Argentina.

PORPINO KO, FERNICOLA JC AND BERGQVIST LP. 2010. Revisiting the intertropical Brazilian species Hoplophorus euphractus (Cingulata, Glyptodontoidea) and the phylogenetic affinities of Hoplophorus. J Vert Paleontol 30: 911-927.

PORPINO KO, FERNICOLA JC, CRUZ L AND BERGQVIST LP. 2014. The intertropical Brazilian species of Panochthus (Xenarthra, Cingulata, Glyptodontoidea): a reappraisal of their taxonomy and phylogenetic affinities. J Vert Paleontol 34: 1165-1179.

REguero MA AND CANDEla AM. 2011. Late Cenozoic mammals from the northwest of Argentina. In: Salfity JA and Marquillas RA(Eds), Cenozoic Geology of the Central Andes of Argentina. SCS Publisher, Salta, Argentina, p. 411-426.
REguero MA, CANDEla AM AND ALONSO RN. 2007. Biochronology and biostratigraphy of the Uquía Formation (Pliocene-early Pleistocene, NW Argentina) and its significance in the Great American Biotic Interchange. J S Am Earth Sci 23: 1-16.

REIG O. 1958. Notas para una actualización del conocimiento de la fauna de la Formación Chapadmalal. I. Lista Faunística Preliminar. Act Geol Lill II: 241-153.

ROVERETO C. 1914. Los estratos araucanos y sus fósiles. An Mus Pub Buenos Aires, p. 1-250.

SCHUltz PH, ZÁRATE M, HAMES W, CAMILIÓN C AND KING J. 1998. A 3.3-Ma impact in Argentina and possible consequences. Science 282: 2061-2063.

SCILlATO-YANÉ GJ. 1977. Sur quelques Glyptodontidae nouveaux (Mammalia, Edentata) du Déséadien (Oligocène inférieur) de Patagonie (Argentine). Bull Mus Natl Hist Nat 64: 249-262.

SCILlATO-YANÉ GJ, CARLINI AA, VIZCAINO SF AND ORTIZ JAUREGUIZAR E. 1995. Los Xenarthros. In: Alberdi et al. (Eds), Evolución biológica y climática de la región Pampeana durante los últimos cinco millones de años. Un ensayo de correlación con el Mediterráneo occidental, Madrid: Museo de Ciencias Naturales, Consejo de Investigaciones, Monografías CSIC 12: 183-209.

SCILlATO-YANÉ GJ, GÓIS F, ZURITA AE, CARlini AA, GonzÁlez Ruiz LR, KRMPOTIC C, Oliva C AND ZAMORANO M. 2013. Los Cingulata (Mammalia, Xenarthra) del "Conglomerado osífero" de la Formación Ituzaingó (Mioceno tardío) de Entre Ríos, Argentina. In: Brandoni D and Noriega JI (Eds), El Neógeno de la Mesopotamia Argentina. Asoc Pal Arg, Pub Esp 14: 112128.

SOIBELZON E, MiÑO-BOILINI AR, ZURITA AE AND KRMPOTIC CM. 2010. Los Xenarthra del Ensenadense (Pleistoceno Inferior a Medio) de la Región Pampeana (Argentina). Rev Mex Cienc Geol 27: 449-469.

SOIBElzON E, ZURITA AE AND CARLINI AA. 2006. Glyptodon munizi Ameghino (Mammalia, Cingulata, Glyptodontidae): redescripción y anatomía. Ameghiniana 43: 377-384.

SOIBELZON L, ZAMORANO M, SCILLATO-YANÉ GJ, PIAZZA D, Rodríguez S, SOIBELzON E, TONNI EP, SAN CRISTOBAL J AND BEILINSON E. 2012. Un Glyptodontidae de gran tamaño en el Holoceno temprano de la región Pampeana. Rev Bras Paleontol 15: 105-112.

TOMASSINI R, MONTALVO CI, DESCHAMPS CM AND MANERA T. 2013. Biostratigraphy and biochronology of the Monte Hermoso Formation (early Pliocene) at its type locality, Buenos Aires Province, Argentina. J S Am E Sc 48: 31-42.

VIZCAÍNO SF, FARIÑA R, ZÁRATE M, BARGO SM AND SCHULTZ P. 2004. Palaeocological implications of the mid-Pliocene faunal turnover in the Pampean Region (Argentina). Palaeogeogr Palaeocl 213: 101-113. 
Zamorano M, TAglioretTi M, ZURita AE, SCILlatoYANÉ GJ AND SCAGLIA F. 2014. El registro más antiguo de Panochthus (Xenarthra, Glyptodontidae). Estud GeolMadrid 70(1): 5-11.

ZÁRATE M. 1989. Estratigrafía y Geología del Cenozoico tardío aflorantes en los acantilados marinos entre Playa San Carlos y el arroyo Chapadmalal, partido de Gral. Pueyrredón, Buenos Aires, Argentina. (Ph.D. thesis). La Plata, Argentina: Facultad de Ciencias Naturales y Museo, Universidad Nacional de La Plata.

ZÁRATE M. 2005. El Cenozoico tardío continental de la provincia de Buenos Aires. In: de Barrio RE et al. (Eds), Geología y Recursos Minerales de la Provincia de Buenos Aires. XVI Congreso Geológico Argentino, La Plata 4. La Plata, Buenos Aires: Asociación Geológica Argentina, p. 139-158.

ZÁRATE MA AND FASANO JL. 1989. The Plio-Pleistocene record of Central Eastern Pampas, Buenos Aires Province, Argentina: The Chapadmalal case study. Palaeogeogr Palaeocl 72: 27-52.

ZURITAAE. 2007a. Sistemática y evolución de los Hoplophorini (Xenarthra, Glyptodontidae, Hoplophorinae. Mioceno tardío-Holoceno temprano). Importancia bioestratigráfica, paleobiogeográfica y paleoambiental. (Ph.D. thesis). La Plata, Argentina: Facultad de Ciencias Naturales y Museo, Universidad Nacional de La Plata.

ZURITA AE. 2007b. Los Hoplophorini (Mammalia, Glyptodontidea) del "Araucanense" (Mioceno tardíoPlioceno) del Noroeste de la Argentina: sistemática, paleobiogeografía y paleoambientes. Ameghiniana 44: 257-269.

Zurita AE, CARlini AA, Gillette D AND SANCHEZ R. 2011a. Late Pliocene Glyptodontinae (Xenarthra, Cingulata, Glyptodontidae) of South and North America: morphology and paleobiogeographical implications in the GABI. J S Am E Sc 31: 178-185.

ZURITA AE, GONZÁLEZ-RUIZ L, GÓMEZ-CRUZ A AND ARENAS-MOSQUERA JE. 2013. The most complete known Neogene Glyptodontidae (Mammalia, Xenarthra, Cingulata) from northern South America: taxonomic, paleobiogeographic and phylogenetic implications. J Vert Paleontol 33: 698-706.

ZURITA AE, MiÑO-BOILINI AR, SOIBELZON E, SCILLATOYANÉ GJ AND PAREDES-RÍOS F. 2009. First record and description of an exceptional unborn specimen of Cingulata Glyptodontidae: Glyptodon Owen (Xenarthra). C R Palevol 8: 573-578.

ZURITA AE, OLIVA C, DONDAS A, SOIBELZON E AND ISLA FI. 2011b. El registro más completo de un Hoplophorini (Xenarthra: Glyptodontidae) para los Pisos/Edades Chapadmalalense-Marplatense (Plioceno tardío-Pleistoceno temprano). Rev Mus Argent Cienc Nat 13: 69-75.

ZURITA AE, OLIVEIRA EV, TORIÑO P, RODRIGUEZ-BUALÓ SM, SCILLATO-YANÉ GJ, LUNA C AND KRAPOVICKAS
J. 2011c. On the taxonomic status of some Glyptodontidae (Mammalia, Xenarthra, Cingulata) from the Pleistocene of South America. Ann Paleontol 97: 63-83.

ZURITA AE, SCILlATO-YANÉ GJ AND CARLINI AA. 2005. Paleozoogeographic, biostratigraphic and systematic aspects of the genus Sclerocalyptus Ameghino 1891 (Xenarthra, Glyptodontidae) of Argentina. J S Am E Sc 20: 121-129.

Zurita AE, SoIBElzon E AND CARLini AA. 2006. Neuryurus (Xenarthra, Glyptodontidae) in the Lujanian (late Pleistocene- early Holocene) of the pampean region. Neues Jahrb Geol P-A 2: 78-88.

Zurita AE, TAgLioretti M, DE LOS REYES M, Oliva C AND SCAGLia F. 2014. First Neogene skulls of Doedicurinae (Xenarthra, Glyptodontidae): morphology and phylogenetic Implications. Hist Biol 28(3): 423-432.

\section{APPENDIX I}

SPECIMENS EXAMINED FOR COMPARATIVE STUDY

Urotherium simplex: MACN Pv 5813 (Type), Castellanos, 1926

Urotherium simile: MFCA 727 (type), MFCA 593, Castellanos, 1948

Urotherium interundatum: MLP M-229 (calco type), Scillato-Yané et al. (2013)

Urotherium antiquum: Ameghino (1889, pl. 62, figs 6 and 7)

Lomaphorus chapadmalensis: MACN Pv 5806 (type) Ameghino (1908)

Lomaphorus cingulatus: MACN A-592 (calco type)

Lomaphorops corallinus: MACN Pv 8331 (type), Rovereto (1914)

Lomaphorus compressus: Ameghino (1889, plate 69, fig. 18).

Lomaphorus imperfectus: Ameghino (1889: pl. 58, figs 1, 2 and 3, and pl. 60, fig. 6)

Trachycalyptus chapadmalensis: MACN Pv 5823

(type), Ameghino in Rovereto (1914)

Paraglyptodon dubius: MACN Pv 6285 (type), Ameghino 1908

Paraglyptodon chapadmalensis: MACN Pv 6162 (type)

Cf. Eleuherocercus antiquus: MMP 4860, 5360, Xen 34, Zurita et al. (2014) 
Neuryurus: MCNL 6.6, Zurita et al. (2006)

Eosclerocalyptus cf. lineatus: Xen 30, Mam-63-4, MMP 4842, 5303, FM 05-266

Eosclerocalyptus proximus: MFCA 676, Zurita (2007b)

Plohophorus figuratus: MLP 16-153, (type) MMP 5300; Xen 72

Neosclerocalyptus paskoensis: Ctes-PZ 5879 (Type), GCF 83
Neosclerocalyptus ornatus: MMP 4600, Zurita (2007a)

Neosclerocalyptus pseudornatus: MACN Pv 7075, (Zurita 2007a)

Neosclerocalyptus sp. : MFCA 758

Glyptodon sp.: PVE-F 85, MNAP-V 6146a, MFCA 760, Zurita et al. (2009, 2011c)

Glyptodon reticulatus: MCA 2017, Zurita et al. (2009) 